\title{
A CASE OF OSTEITIS FIBROSA CYSTICA (OSTEOMALACIA?) WITH EVIDENCE OF HYPERACTIVITY OF THE PARA- THYROID BODIES. METABOLIC STUDY II $^{\mathrm{I}}$
}

\author{
By WALTER BAUER, ${ }^{2}$ FULLER ALBRIGHT ${ }^{3}$ AND JOSEPH C. AUB \\ (From the Medical Clinic of the Massachusetts General Hospital, Boston)
}

(Received for publication February 5, 1929)

\section{INTRODUCTION}

In a previous paper (1) we have pointed out certain characteristic responses in the calcium and phosphorus metabolisms resulting from parathormone ${ }^{4}$ administration to essentially normal individuals. In the present paper, similar studies will be reported on a patient who presented a condition suggestive of idiopathic hyperparathyroidism.

\section{CASE HISTORY}

The patient, Mr. C. M., sea captain, aged 30, was transferred from the Bellevue Hospital Service to the Special Study Ward of the Massachusetts General Hospital through the courtesy of Dr. Eugene F. DuBois, for further investigation of his calcium metabolism and for consideration of parathyroidectomy. His complete case history has been reported by Hannon, Shorr, McClellan and DuBois (2). It describes a man invalided for over three years with symptoms resulting from a generalized skeletal decalcification. (See x-rays, figs. 1 to 4.)

${ }^{1}$ This is No. VII of the series entitled "Studies of Calcium and Phosphorus Metabolism" from the Medical Clinic of the Massachusetts General Hospital.

${ }^{2}$ Resident Physician, Massachusetts General Hospital.

${ }^{3}$ Research Fellow, Massachusetts General Hospital and Harvard Medical School.

${ }^{4}$ Parathormone is Eli Lilly and Co.'s trade name for Collip's parathyroid extract. 


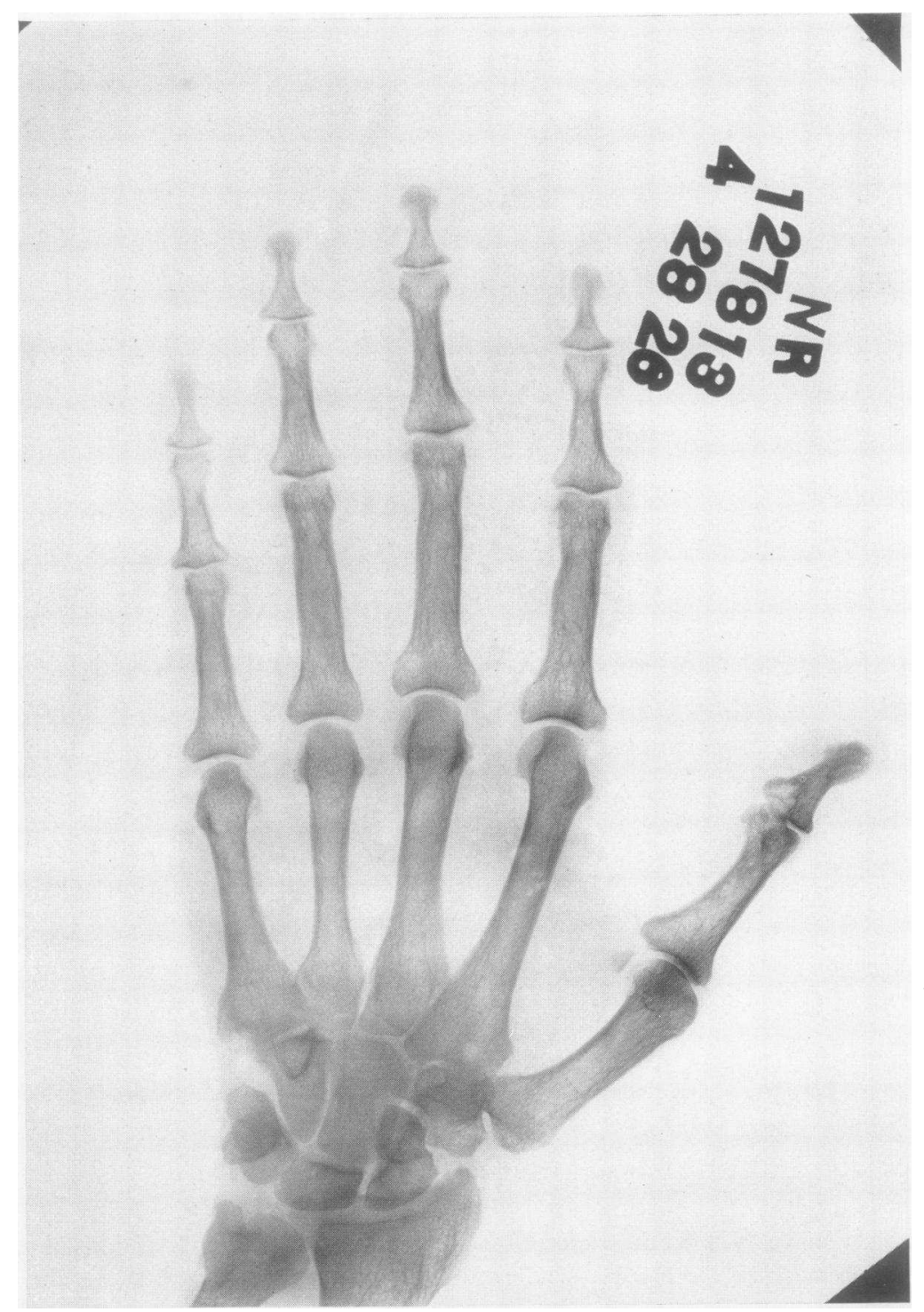

Fig. 1. X-ray of Right Hand Showing Moderate Generalized Decalcification and Coarse Trabeculations 


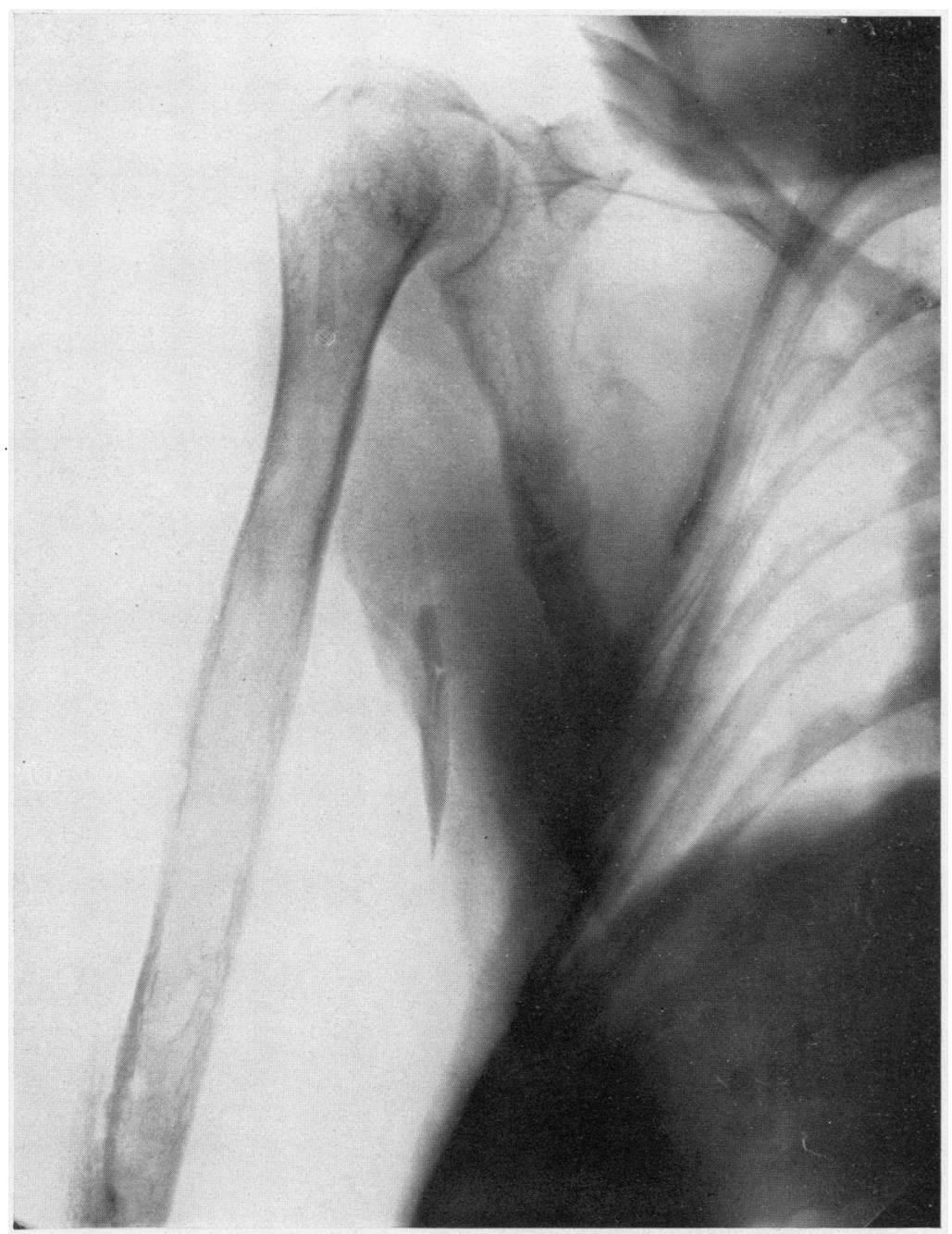

Fig. 2. X-Ray of Right Shoulder Showing Old Fracture at the Lower End of the Humerus. Absence of Most of the Bone Trabeculae in the Middle Half, with Thinning of the Cortex and Slight Bulging of the Shaft. Also Indefinitely Defined Cystic Areas in the Lower THIRD. 


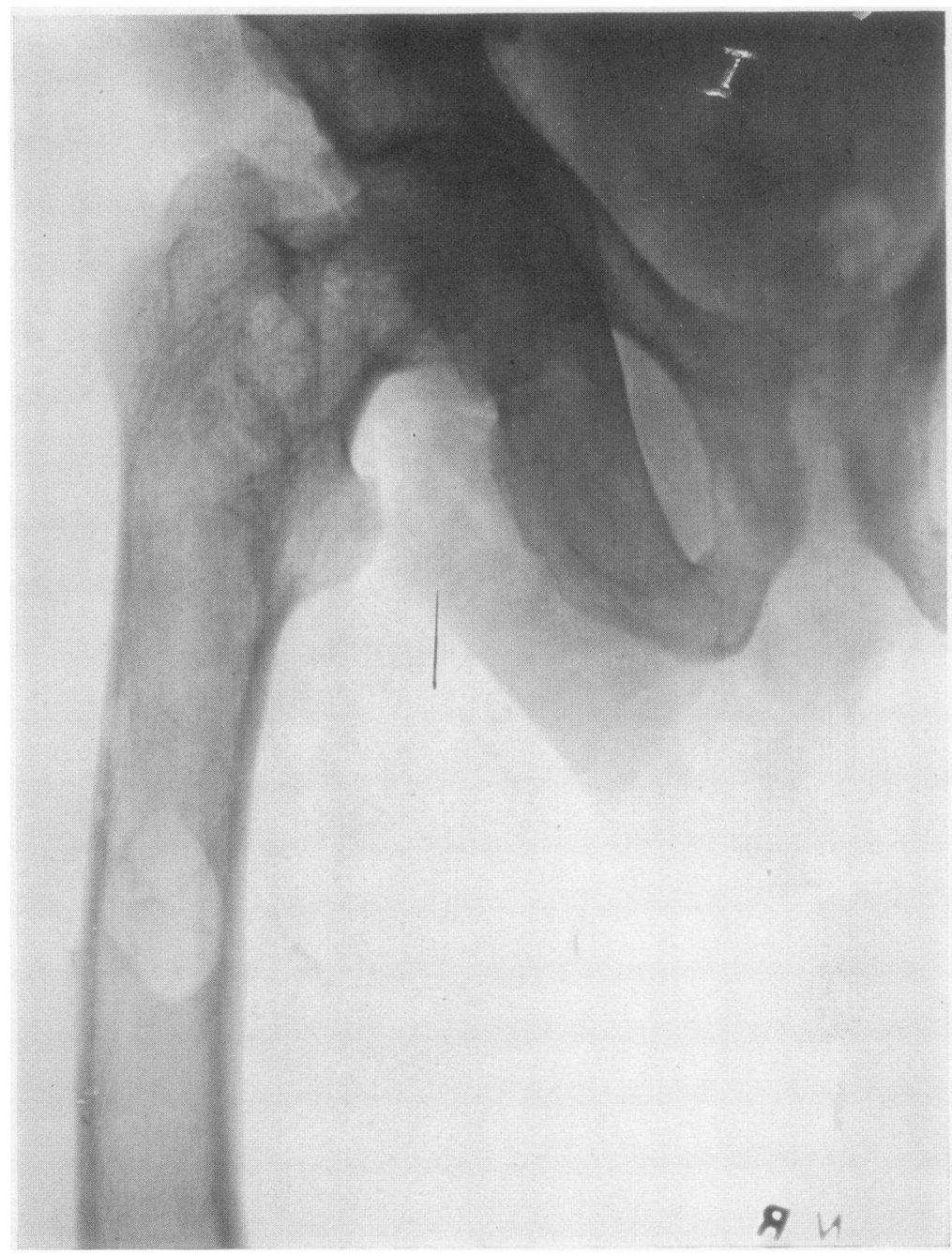

Fig. 3. X-ray of Right Femur Showing a Cystic Area About 1 Inch in DIAMETER IN THE UPPER THIRD

Just above and lateral to this area are two smaller areas of similar appearance 


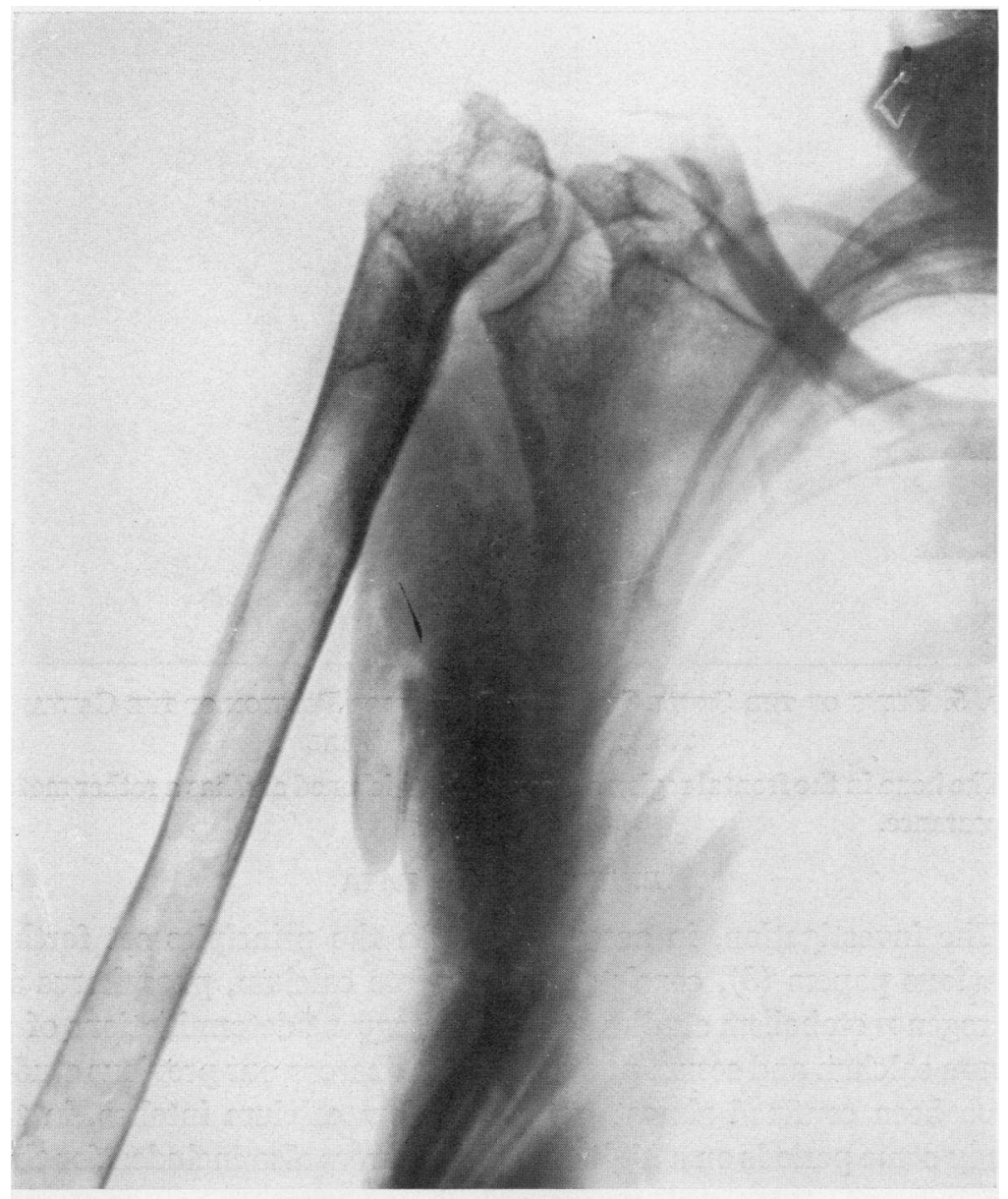

Fig. 4. X-Ray of the Left Humerus Showing Well-defined Atrophy with Thinning of the Cortex and Irregularity in the Head of the HuMERUS IN THE REgION OF THE TUBEROSITY. 


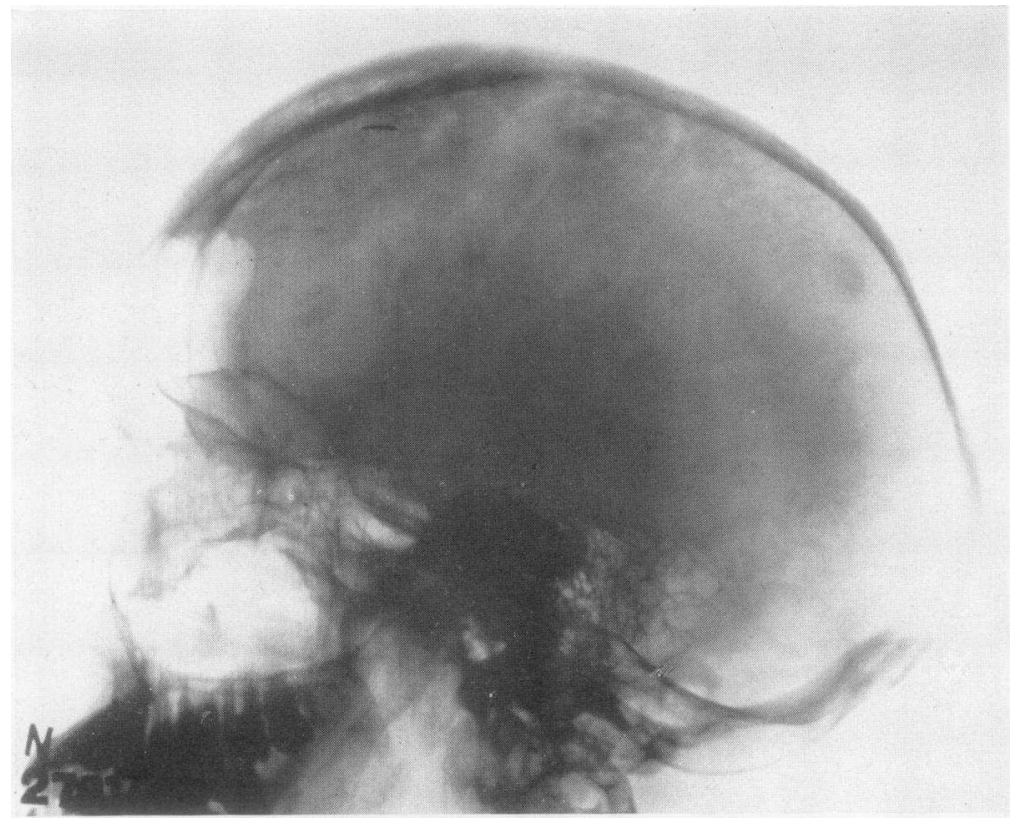

Fig. 5. Fit.ms of the Skull Show the Posterior Portion of the Calvarium to be Thinner than Usual

The bone in the frontal region appears to be thickened and has a rather mottled appearance.

EXPERIMENTAL DATA

The investigation, in accordance with the principles set forth in previous papers (3), consisted of complete calcium, phosphorus and nitrogen metabolism studies as well as frequent determinations of the serum calcium and serum phosphorus. Whereas our previous studies have been confined almost entirely to low calcium intakes, in this study some periods on a high calcium diet were also included for three reasons. In the first place, we wished to confirm the findings of the Cornell group, who had studied this patient while on a relatively high calcium diet. Secondly, it seemed essential from a therapeutic standpoint to determine whether a positive calcium balance could be maintained on a high calcium diet. Lastly, because of the patient's marked skeletal decalcification, it was not considered wise to study him for more than a very short period on a low calcium diet.

During the patient's stay in the Hospital, two normal parathyroid glands were removed by Dr. Edward P. Richardson. Our studies include periods of high and low calcium diet before and after the operations. 
The methods employed in the collection of the excreta and in the analyses of the material have been given in previous papers (3 and 4). The details of the operations and the pathological reports of the tissues removed are given in the appendix (q. v.). The essential point is that two normal appearing parathyroid glands were removed at operation.

\section{RESULTS}

In table 1 and charts $1 \mathrm{~A}, 1 \mathrm{~B}$, and $1 \mathrm{C}$ are found the data for the calcium, phosphorus and nitrogen excretion. Each study period is three days unless otherwise indicated. In table 1 are also included the serum calcium and serum phosphorus values.

\section{A. Serum calcium and serum phosphorus}

On examination of these blood findings one notes that the serum calcium is markedly elevated above normal and that the serum phosphorus is considerably reduced below normal; indeed relatively more than the serum calcium is elevated. Such a fall of the blood phosphorus we have found to be the case on administration of parathormone, provided that the serum calcium does not rise sufficiently high to produce a secondary phenomenon which is associated with a marked increase of the serum phosphorus. The serum calcium in this patient was not sufficiently high to produce this phenomenon and the low serum phosphorus is in accordance with the findings in patients receiving parathormone. The removal of the two parathyroid glands was apparently without effect on the blood findings.

\section{B. Metabolism findings}

The discussion of the metabolic findings (table 1 and charts $1 \mathrm{~A}, 1 \mathrm{~B}$ and $1 \mathrm{C}$ ) will be divided into four parts.

$a$. A comparison of the findings before operation, while the patient was on a low calcium diet, with those of normal individuals on a similar diet.

$b$. A comparison of the findings in respect to both calcium and phosphorus metabolism before operation while the patient was on a low calcium diet with those of an individual receiving 100 units of parathormone per day. 


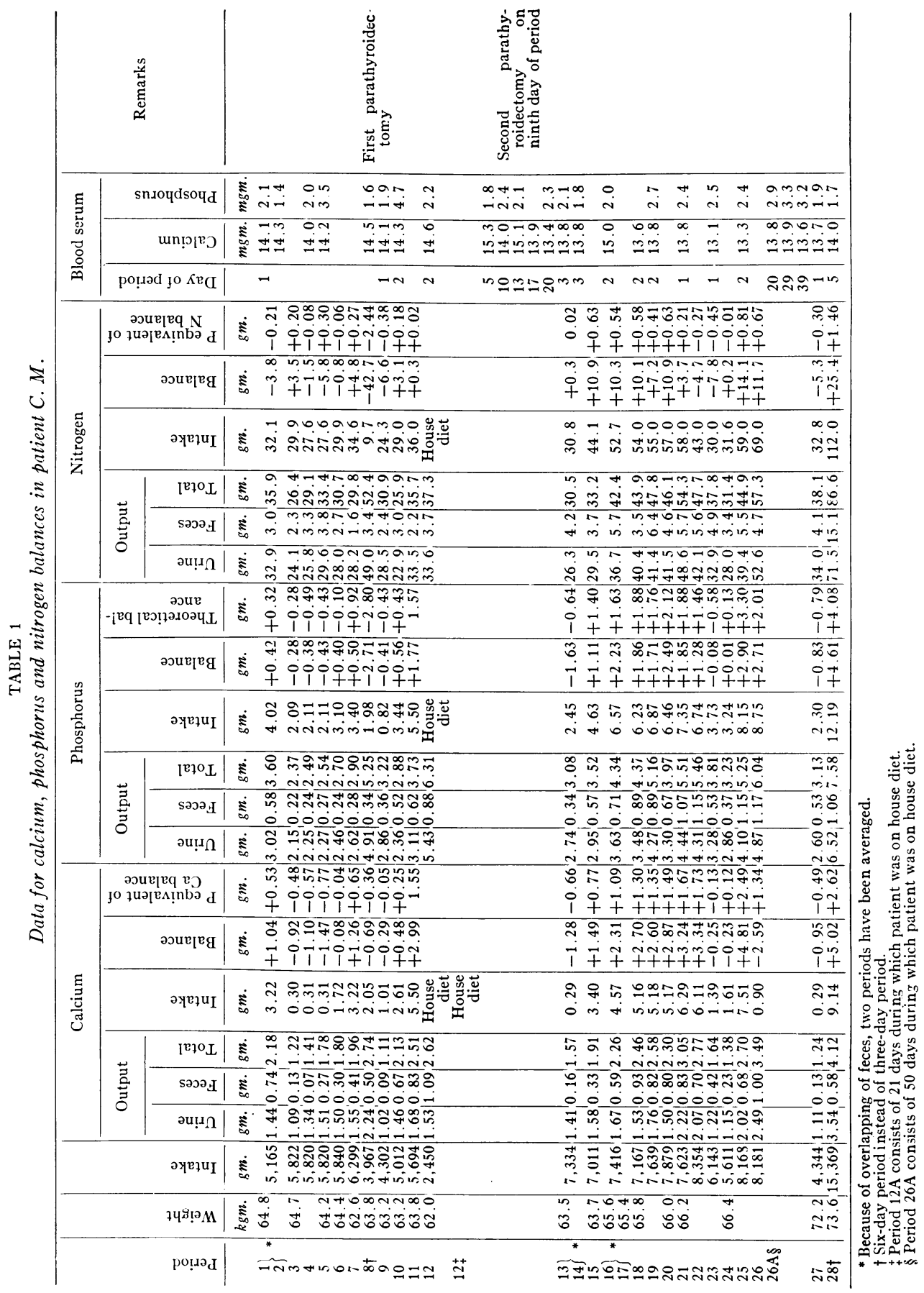


c. A comparison of the findings while the patient was on a high calcium diet with the findings of the Cornell group (2).

$d$. A comparison of the findings, during both high and low calcium periods before operation, with similar periods after operation.

In a previous paper (3) giving the calcium excretion of normal individuals on a low calcium diet, it was pointed out that before

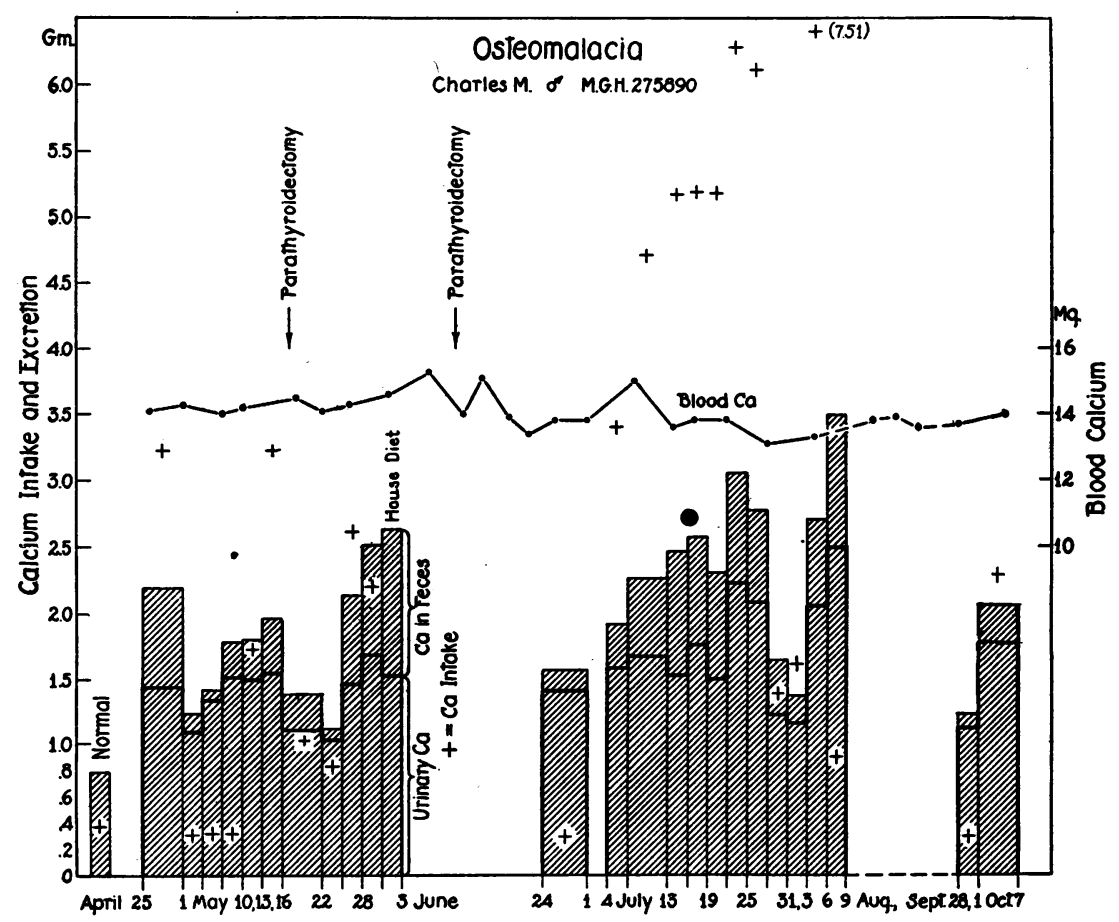

Chart 1A. Showing Graphically the Calcium Metabolism Data from TABLE 1

quantitative comparisons could be made with regard to the calcium metabolism between individuals, factors had to be introduced which took into account the sex, age, weight, activity, acid-base balance of diet, proportion of other bases in diet, and phosphorus metabolism. This patient (male, age 30, weight $64 \mathrm{kgm}$.) compares favorably with the controls (all male, average age 41 , average weight $62 \mathrm{kgm}$.). The diet of the patient was picked from the same limited menu as that 
of the control patients so that the acid-base values and cation contents should be approximately equal. As regards activity, this patient was in bed until periods 26 and 28 as compared with mild activity on the part of the controls. Except for period 7, the patient remained essentially in nitrogen balance. In table 2, the average values for the three low calcium periods before operation (periods 3,4 and 5) are compared with the average values of the control series (3). One

TABLE 2

Comparison of preoperative period of $C . M$. with controls

\begin{tabular}{c|c|c|c|c|c}
\hline & \multicolumn{4}{|c}{ Calcium } \\
\cline { 2 - 5 } & \multicolumn{3}{|c|}{ Output } & Intake & Balance \\
\cline { 2 - 5 } & Urine & Feces & Total & & \\
\hline Control series $(3) \ldots \ldots \ldots \ldots \ldots \ldots$. & 0.19 & 0.60 & 0.79 & 0.33 & -0.46 \\
Average of periods 3,4, and 5 on $\mathrm{Mr}$. & & & & & \\
C. M......................... & 1.31 & 0.19 & 1.50 & 0.31 & -1.29 \\
\hline
\end{tabular}

TABLE 3

Comparison of preoperative periods of C.M. with a normal individual receiving parathormone

\begin{tabular}{|c|c|c|c|c|c|c|}
\hline & \multicolumn{6}{|c|}{ Calcium } \\
\hline & \multicolumn{3}{|c|}{ Output } & \multirow{2}{*}{ Intake } & \multirow{2}{*}{$\begin{array}{l}\text { Bal- } \\
\text { ance }\end{array}$} & \multirow{2}{*}{ Serum calcium } \\
\hline & Urine & Feces & Total & & & \\
\hline \multirow{3}{*}{$\begin{array}{l}\text { Patient receiving } 100 \text { units of para- } \\
\text { thormone daily (average of } 4 \\
\text { periods) } \ldots \ldots \ldots \ldots \ldots \ldots \ldots \ldots \ldots \ldots \ldots\end{array}$} & gm. & gm. & gm. & gm. & gm. & mgm. per 100.cc. \\
\hline & 1.33 & 0.45 & 1.78 & 0.34 & -1.44 & $11.5-12.8$ \\
\hline & & & & & & \\
\hline Mr. C. M. $\ldots \ldots \ldots \ldots \ldots \ldots \ldots$ & 1.31 & 0.19 & 1.50 & 0.31 & $-1.29 \mid$ & $13.1-15.3$ \\
\hline
\end{tabular}

notes from table 2 that the negative calcium balance on a low calcium diet is markedly increased in this patient and that this increase is entirely due to an increased urinary calcium excretion, the fecal calcium excretion being actually decreased.

It is now of interest to compare the findings in this patient with those of an essentially normal individual receiving 100 units of parathormone a day (Mr. W. S. (1)). The calcium figures are shown in table 3 and indicate that the calcium metabolism of this patient while on a low 
calcium diet is qualitatively and quantitatively similar to an individual receiving 100 units of parathormone.

From table 1 and chart 1B, it will be noted that phosphorus was lost from the body coincident with the calcium loss. It will be further noted that an unusually large proportion of the phosphorus

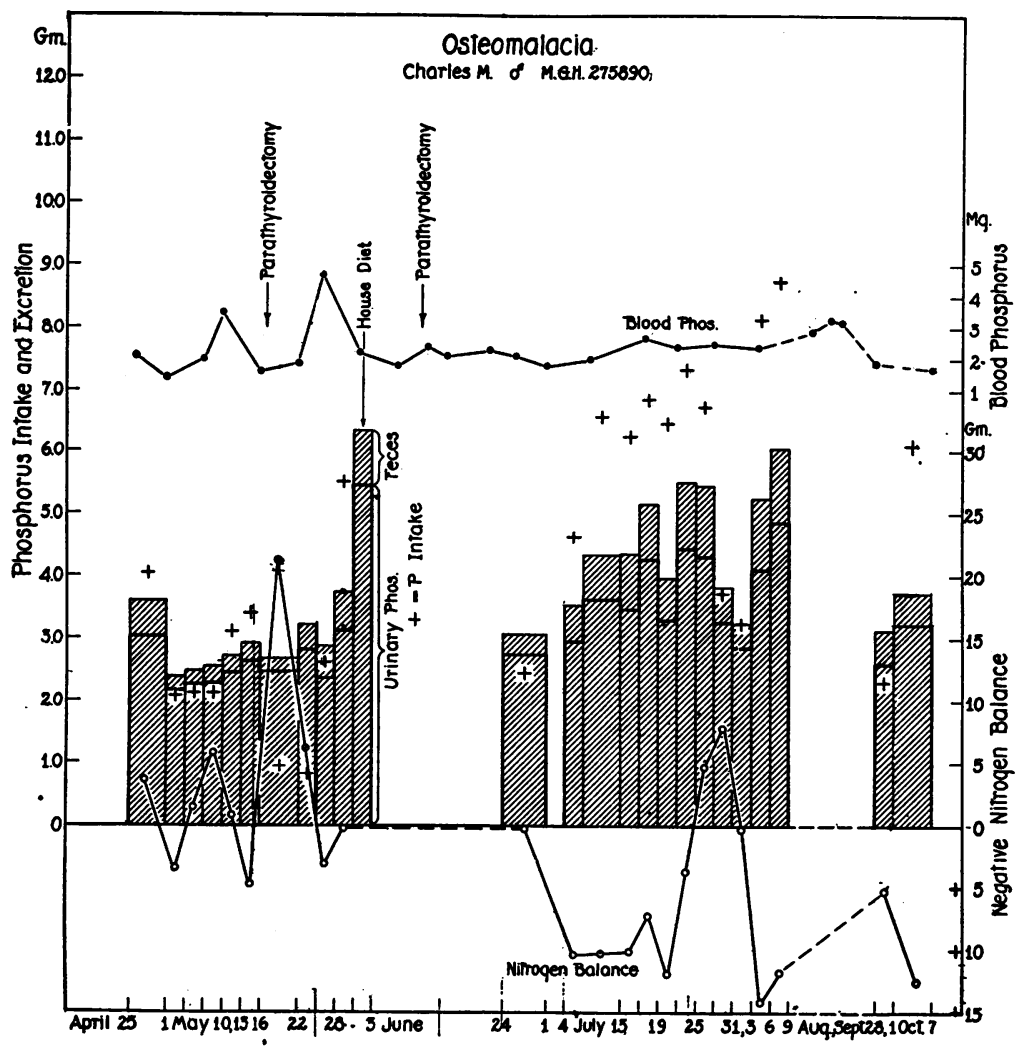

Chart 1B. Representing the Phosphorus Metabolism Data from Table 1

was excreted in the urine. In chart $1 \mathrm{C}$, if one makes the assumption that the calcium and phosphorus losses represent tertiary calcium phosphate withdrawn from the bones, this phosphorus loss is shown to be closely in agreement with the calcium loss. The "theoretical phosphorus balance" in chart $1 \mathrm{C}$ is the sum of the phosphorus equivalent of the nitrogen balance $(\mathrm{N} / \mathrm{P}$ in protein $=17.4)$ and 
the phosphorus equivalent of the calcium balance $(\mathrm{Ca} / \mathrm{P}$ in tertiary calcium phosphate $=1.93)^{5}$ and has been discussed at length in paper 3 of this series (1). The close agreement of the actual and

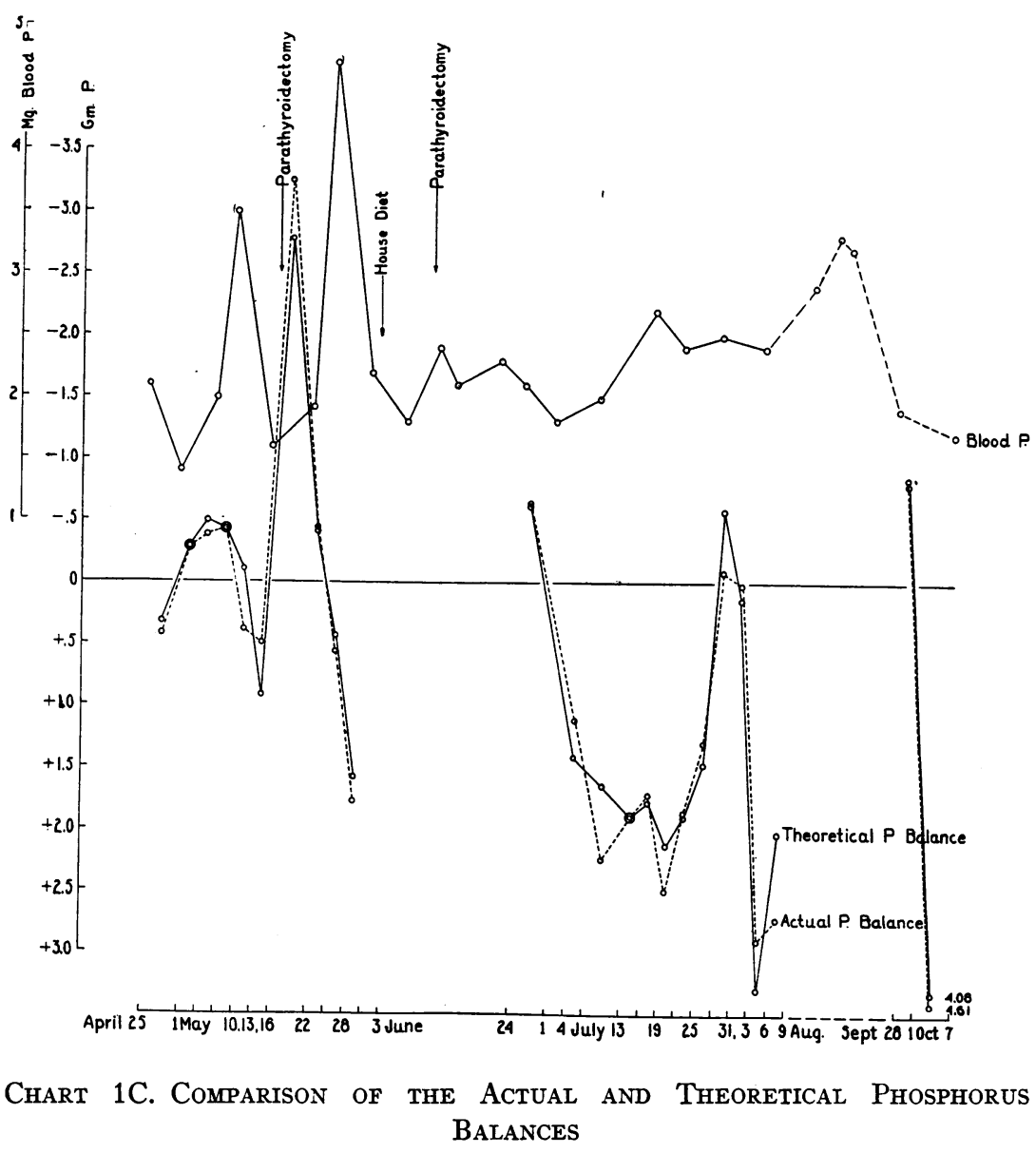

theoretical phosphorus balances in chart $1 \mathrm{C}$ is consistent with a constant degree of hyperparathyroidism; and is in contradistinction to what takes place when shifts are made from a lesser to a greater degree of hyperparathyroidism by injection of parathyroid extract (1).

${ }^{5}$ The factor 1.93 was used in this paper and represents the ratio of $\mathrm{Ca} / \mathrm{P}$ in $\mathrm{Ca}_{3}\left(\mathrm{PO}_{4}\right)_{2}$. In paper 3 of this series (1), the factor 2.23 was used which represents the ratio of $\mathrm{Ca} / \mathrm{P}$ in bone. 
Thus we may conclude that the calcium and phosphorus metabolism of this patient before operation was consistent with that of persons receiving large doses of parathyroid extract.

TABLE 4

Comparing C. M. on high calcium intake as studied in two clinics

\begin{tabular}{|c|c|c|c|c|c|c|}
\hline & \multicolumn{5}{|c|}{ Calcium } & \multirow{3}{*}{$\begin{array}{l}\text { Nitro- } \\
\text { gen } \\
\text { balance }\end{array}$} \\
\hline & \multicolumn{3}{|c|}{ Output } & \multirow{2}{*}{ Intake } & \multirow{2}{*}{$\begin{array}{l}\text { Bal- } \\
\text { ance }\end{array}$} & \\
\hline & Urine & Feces & Total & & & \\
\hline & $g m$. & $g m$. & $g m$. & $\mathrm{gm}$. & $g m$. & $\mathrm{gm}$. \\
\hline $\begin{array}{l}\text { Average of periods } 1,2 \text { and } 7 \text { on } \mathrm{Mr} . \mathrm{C} . \mathrm{M} . \ldots \\
\text { Average of } 3 \text { periods of investigations by }\end{array}$ & 1.48 & 0.64 & 2.12 & 3.22 & +1.10 & +8.6 \\
\hline Cornell group (2) on Mr. C. M......... & 1.98 & 0.41 & 2.39 & 2.72 & +0.33 & -0.9 \\
\hline
\end{tabular}

TABLE 5

Comparison of C. M. on high and low calcium intake before and after operation

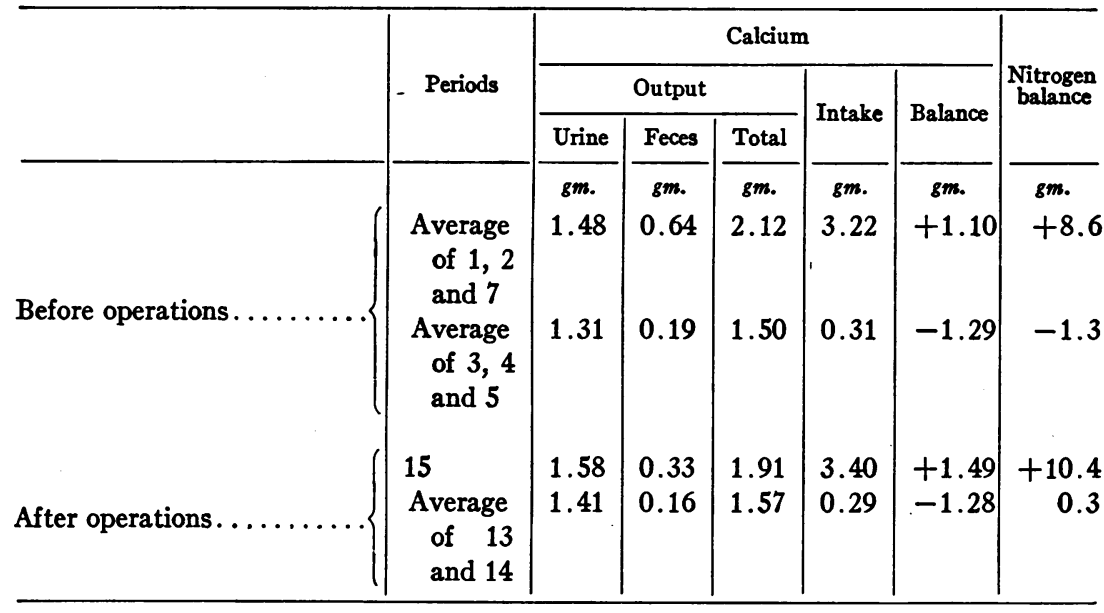

It was extremely important for the patient's welfare to know whether he could be kept on a positive calcium balance by dietary measures. Therefore, he was studied on a high calcium diet. ${ }^{6}$

In table 4 are given these data with those obtained by the Cornell

- The principles suggested by later investigations (1) were not understood at the time of this study, or else a high phosphorus diet would have been tried as well as a high calcium diet. 
group under a somewhat similar regime (2). Our figures are roughly in agreement with those of the Cornell group provided that the difference in calcium intakes is taken into consideration. Furthermore, it will be seen that on a fairly high calcium intake it was possible before operation to keep this patient in a positive calcium balance. It should be noted, however, that the phosphorus content of our high calcium diet was considerably higher than that of our low calcium diet (see table 1). In view of later investigations (1) this may have been a determining factor in the establishment of a positive calcium balance.

Finally, we wish to note the effect of the removal of two apparently normal parathyroid glands on the calcium metabolism. Therefore, table 5 has been prepared in which figures are given for both low and high calcium periods before and after the operations. As with the blood findings ( $v$. supra) the operations seem to have had very little if any effect on the calcium metabolism.

The fact that his calcium excretion seemed to be maintained at a fairly constant level whether he was on a low or a high calcium intake made it possible for him to store calcium when he was given a large amount in the diet. By this means, enough calcium was deposited to be demonstrable by $\mathrm{x}$-ray pictures of his bones. Since leaving the hospital he hass maintained this high diet and has been able to get out of bed and work without having any further fractures. Now, two years after these original observations, his fasting blood serum calcium is $12.4 \mathrm{mgm}$. and blood phosphorus is $2.4 \mathrm{mgm}$. by the Fiske methods. $\mathrm{X}$-ray pictures of his bones still show cysts but demonstrate some thickening and further deposits of calcium salts.

\section{DISCUSSION}

The calcium and phosphorus metabolisms and the levels of the serum calcium and phosphorus in this patient have been shown to be abnormal. Moreover, the deviations from normal have been shown to be in the same directions and of approximately the same degree as those in an individual receiving large doses of parathormone, and are in the opposite directions from individuals suffering from hypoparathyroidism (6). Therefore, in spite of lack of confirmation at operation, 
we feel justified in concurring with the diagnosis of hyperparathyroidism suggested by Dr. Eugene F. DuBois.

Such a diagnosis, though rare, is nevertheless, not without precedent in the literature. ${ }^{7}$ In 1926 Mandl (7) (8) presented a case report of a man 38 years old, incapacitated by generalized osteitis fibrosa, who was greatly improved following the extirpation of a parathyroid tumor. The serum calcium which was $18.2 \mathrm{mgm}$. before operation fell to $12 \mathrm{mgm}$. after operation. Following the operation there was a marked retention of calcium as demonstrated by $\mathbf{x}$-rays and a gradual improvement in all symptoms. Mandl (8) in summary, gives an excellent review of the literature of the various bone conditions in which parathyroid lesions have

TABLE 6

List of cases examined for parathyroid lesions

\begin{tabular}{|c|c|c|c|}
\hline Author. & $\begin{array}{l}\text { Number } \\
\text { of cases }\end{array}$ & Bone disorder & Character of parathyroids \\
\hline Todyo (15)...... & 24 & Absent & 4 showed hypertrophy \\
\hline Hartwick (16) ......... & 22 & Absent & Normal \\
\hline Hártwick (16)....... & 15 & Rickets & Normal \\
\hline Schmorl $(17) \ldots \ldots \ldots$ & 4 & Rickets & 1 showed hypertrophy \\
\hline Schmorl (17)..... & 2 & Senile osteoporosis & Normal \\
\hline Strada $(18) \ldots \ldots \ldots$ & 2 & Senile osteoporosis & Normal \\
\hline Maresch (19) ......... & 28 & Senile osteoporosis & Normal \\
\hline Maresch (19)......... & 5 & Osteitis deformans & Normal \\
\hline Maresch (19)... & 1 & Absent & Large cystic tumor \\
\hline Danisch $(20) \ldots$ & 23 & Osteomalacia & 19 showed hypertrophy \\
\hline Strada (18) .... & 1 & Osteomalacia & Normal \\
\hline Thomas $(21) \ldots \ldots$ & 30 & Osteomalacia & 6 showed hypertrophy \\
\hline Maresch (19)...... & 8 & Senile osteomalacia & Normal \\
\hline
\end{tabular}

been found. This summary contains 82 cases (including his own) reported by 36 authors. Search of the literature confirmed all of these cases and resulted in the finding of six additional cases. These six cases are:

1. 1907 Von Verbély (9) - 42 year old female - diffuse adenoma of a parathyroid gland with osetomalacia.

2. 1911 Bauer (10)-45 year old female-parathyroid tumor with osteomalacia.

3. 1912 Hohlbaum (11)-hypertrophy of the parathyroids with osteomalacia.

${ }^{7}$ Since this paper was written, similar cases have been reported (24), (25), (26), (27), (28), (29), (30), (31), (32) and (33). 
4. 1923 Klemperer (12) - tumor of parathyroid with multiple bone metastases from carcinoma of breast.

5. 1924 Ritter (13) -2 year old female - enlargement of four parathyroids with rickets.

6. 1925 Ferrero, J. and Sacerdote, G. (14) -65 year old female-parathyroid tumor with benign metastases of parathyroid tumor to femur and temporal bones.

Of the 88 cases of bone disorders associated with parathyroid lesions, 14 showed tumors and the rest hyperplasia of the parathyroid glands. Of the cases in which hyperplasia was found, 21 were associated with osteomalacia, 15 with osteitis fibrosis, 3 with rickets, 6 with senile osteomalacia, and 28 with senile osteoporosis. In the cases of parathyroid tumors, 9 were associated with osteitis fibrosa, 1 with osteomalacia, 1 with benign parathyroid tumor metastases to the temporal and femur bones, and 1 with multiple bone metastases from a breast carcinoma.

Table 6 taken from the literature shows in summary form various types of conditions which have been examined for question of associated parathyroid pathology and the number in which pathological glands were found. Thus, in 46 normal cases examined, hypertrophy was present in 4 . In 19 cases of rickets 1 showed hypertrophy. The parathyroids were normal in 32 cases of senile osteoporosis, 5 cases of osteitis deformans and 8 cases of senile osteomalacia. Of 54 cases of osteomalacia examined, 25 showed hypertrophy. One normal case presented a large cystic parathyroid tumor.

Except for Mandl's case, all the pathological parathyroids associated with bone disorders were found at autopsy. The occurrence of a bone lesion and a lesion of the parathyroids together does not necessarily mean that the two are interrelated, unless there is some clinical evidence of disfunction of the parathyroid glands such as an alteration oi the serum calcium or calcium excretion. In Mandl's case and the one here reported this pre-mortem evidence is present. Unlike Mandl, however, we were unable to find a pathological parathyroid gland. Our failure to find an abnormal gland, on the other hand, does not prove that one does not exist.

In a previous paper evidence has been introduced which suggested that the increased calcium excretion and the increased serum calcium in hyperparathyroidism may be dependent on an increased phosphorus excretion and a depletion of the body's fluid phosphorus (1). In this connection it is of interest to note the picture which results when the body's supply of phosphorus is depleted by insufficient phosphorus intake. This experiment has been performed by nature on cows and reported recently by Palmer and Eckles (22). In certain regions where the grass has a very low phosphorus content, cows develop a 
condition called osteophagia, so called because of their ravenous desire to eat bones. The pathological findings in this condition consists of extreme skeletal decalcification, high serum calcium and low serum phosphorus. In other words, these cows are an exact counterpart of the patient here reported. By adding phosphorus to the diet of the cows the serum phosphorus was elevated; the serum calcium was lowered, and calcium deposition set in. Likewise Karelitz and Shohl, in studies on the production of rickets in rats by low phosphorus high calcium diets (23), produced skeletal decalcification and a low serum phosphorus, but only, a slightly (if at all) elevated serum calcium. On addition of phosphorus to this diet, there was a rapid healing of the rickets with a fall in the serum calcium (11 to 5 $\mathrm{mgm}$.) and a rise in the serum phosphorus (3 to $16 \mathrm{mgm}$.). Therefore, if the calcium abnormalities in our case are a result of an increased phosphorus excretion and a depletion of the body's supply of phosphorus, the logical therapeutic step would be a high phosphorus diet. Under such a regime it seems possible that as striking an improvement might be made as was made by the cows of Palmer and Eckles and the rats of Karelitz and Shohl. It is to be hoped that such a study can be arranged in the near future.

\section{SUMMARY}

1: The calcium, phosphorus and nitrogen metabolisms have been studied in a case with generalized decalcification.

2. The patient's negative calcium balance on a low calcium diet was markedly increased over that found in our normal controls.

3 . This increase was due to an increased urinary calcium excretion. The fecal calcium excretion was actually less than normal.

4. The calcium metabolism findings, like the blood serum findings, are compared with similar data in a man receiving 100 units of parathormone a day and are found to be almost identical.

5. On a high calcium diet the urinary calcium was not increased and the patient remained in calcium balance.

6. The calcium abnormalities were unaffected by the removal of two apparently normal parathyroid glands.

7. Because the pathological physiology in this case is similar to 
that in an individual receiving large doses of parathormone and diametrically opposite to that in a patient with parathyroid tetany, we feel justified in concurring in the diagnosis of hyperparathyroidism suggested by Dr. Eugene F. DuBois.

8. It is pointed out that a high phosphorus diet might be more efficacious from a therapeutic standpoint than a high calcium diet in this case.

\section{APPENDIX}

- First operation by Dr. E. P. Richardson. "Right parathyroidectomy. Curved incision downward over carotid sheath turning across median line above the suprasternal notch. Sterno-mastoid retracted outward and prethyroid muscles divided, exposing anterior surface of thyroid which was of normal size and even consistency but pale. The carotid sheath was retracted outward. The right lobe of the thyroid was then turned toward the median line. Its posterior surface and surrounding areolar tissue was carefully searched for parathyroids. The inferior thyroid artery and recurrent laryngeal nerve, crossing the front was exposed in this dissection. The dissection was carried toward the median line. The inferior thyroid artery entered about the middle of the posterior lobe. There was a large anastomotic branch joining the superior thyroid. No parathyroid tissue was found until after the division of the inferior artery. Just to the median side of this point there was a small vascular area $6 \mathrm{~mm}$. in diameter, deeper red than the remainder of the thyroid lobe. This area was flattened and encapsulated. It was dissected off and thought to be parathyroid. Slightly to the median line from this another smaller area, not so distinctly encapsulated, was removed. Thyroid replaced, muscles sutured. Wound closed without drainage."

Histological report: "Parathyroid glands: Microscopic examination shows one nodule out of five having the structure of a parathyroid gland."

Second operation by Dr. E. P. Richardson. "Exploration of thyroid. Curved incision extending across the neck partly through the old scar and exposing the thyroid lobe. Thyroid lobe turned towards the median line, the posterior aspect carefully dissected. No evidence of adenoma of parathyroid. No structures resembling normal parathyroid glands were seen. Since the parathyroid removed on the other side resembled normal fat, six lobules of fat were removed from the region of the posterior aspect of the thyroid. One of these lying adjacent to the inferior thyroid artery at about the middle of the glands seemed to be a possible parathyroid gland. Wound closed."

Histological report: "Region of parathyroid: Microscopic section of six small specimens showed one which is labelled 'inferior thyroid artery' with the structure of the parathyroid gland. The remainder are composed of lymphoid tissue and fat." 


\section{BIBLIOGRAPHY}

1. Albright, F., Bauer, W., Ropes, M., and Aub, J. C., J. Clin. Invest., 1929, vii, 139. Studies of Calcium and Phosphorus Metabolism. IV. The Effect of the Parathyroid Hormone.

2. Hannon, R. R., Shoir, E., McClellan, W. S., and Du Bois, E. F., J. Clin. Invest., 1930, viii, 215. A Case of Osteitis Fibrosa Cystica (Osteomalacia?) with Evidence of Hyperactivity of Parathyroid Bodies. Metabolic Study I.

3. Bauer, W., Albright, F., and Aub, J. C., J. Clin. Invest. 1929, vii, 75. Studies of Calcium and Phosphorus Metabolism. II. The Calcium Excretion of Normal Individuals on a Low Calcium Diet, Including Data on a Case of Pregnancy.

4. Bauer, W., and Aub, J. C., J. Am. Diet. Assoc., 1927, iii, 106. Studies in Inorganic Salt Metabolism; Ward Routine and Methods.

5. Albright, F., and Bauer, W., To be published. The Effect of the Parathyroid Hormone on the Relation of Serum Calcium to Serum Phosphorus.

6. Bauer, W., Albright, F., Rossmeisl, E., and Aub, J. C., To be published. Studies of Calcium and Phosphorus Metabolism. VI. The Calcium and Phosphorus Metabolism in Parathyroid Tetany with Observations on the Therapeutic Action of Thyroid and Ammonium Chloride Medication.

7. Mandl, F., Zentralbl. f. Chir. 1926, liii, 260. Therapeutischer Veruch bei einem Falle von Ostitis fibrosa generalisata mittels Exstirpation eines Epithelkörperchentumors.

8. Mandl, F., Arch. f. Klin. Chir., 1926, cxliii, 1. Klinisches und Experimentelles zur Frage der lokalisierten und generalisierten Osteitis fibrosa.

9. Von Verebély, T., Virchow's Arch. f. path. Anat., 1907, clxxxvii, 80. Beiträge Zur Pathologie der branchialen Epithelkörperchen.

10. Bauer, T., Frankf. Ztschr. f. Path. 1911, vii, 231. Über das Verhalten der Epithelkörperchen bei der Osteomalacie.

11. Hohlbaum, J., Beitr. z. Path. Anat. u. z. allg. Path. 1912, liii, 91. Beiträge zur Kenntnis der Epithelkörperchenfunktionen.

12. Klemperer, P., Surg., Gynec., Obst. 1923, xxxvi, 11. Parathyroid hyperplasia and bone destruction in generalized carcinomatosis.

13. Ritter, C., Frankf. Ztschr. f. Path., Munch. u. Wiesb. 1920, xxiv, 137. Über Epithelkörperchenbefunde bei Rachitis und anderen Knockenerkrankungen.

14. Ferrero, V., and Sacerdote, G. Arch. ital. di. chir. 1925, xiv, 274. Tumori tireoidei e paratireoidei nelle ossa.

15. Todyo, R., Frankf. Ztschr. f. Path. 1912, x, 219. Utber das Verhalten der Epithelkörperchen bei Osteomalacie und Osteoporose.

16. Hartwich, A., Virchow's Arch. f. path. Anat., 1922, ccxxxvi, 61. Beiträge Zur Rolle der Epithelkörperchen in der Pathologie. 
17. Schmorl, G., Munch. Med. Wchnschr. 1907, liv, 583. Ueber die Pathogenese der bei Morbus Barlow auftretenden Knochenveränderungen.

18. Strada, F., Path. riv. quindicin 1908/9, i, 423-437. Le paratiroidi nell' osteomalacia e nell' osteoporosi senile.

19. Maresch, R., Frankf. Ztschr. f. Path. 1916, xix, 159. Beiträge zur Kenntnis der Hyperplasien und Tumoren der Epithelkörper.

20. Danisch, F., Frankf. Ztschr. f. Path. 1924, xxx, 443. Die menschlichen Epithelkörperchen im Senium.

21. Thomas, quoted by Biedl, A., Inner Sekretion. Berlin, 1922.

22. Palmer, L. S., and Eckles, C. H., Proc. Soc. Exper. Biol. and Med., 1927, xxiv, 307. Effect of Phosphorus Deficient Rations on Blood Composition in Cattle.

23. Karelitz, S., and Shohl, A. T., J. Biol. Chem. 1927, lxxiii, 665 . Rickets in Rats. II. The Effert of Phosphate Added to the Diet of Ricketic Rats.

24. Gold, E., Mitt. a. d. Grenzgeb. d. Med. u. Chir., 1928, xli, 63. Ueber die Bedeutung der Epithelkörpervergrösserung Ostitis fibrosa generalisata Recklinghausen.

25. Lambrie, C. G., Brit. Med. J., 1927, ii, 785. Case Report.

26. Barrenscheen, H. K., and Gold, E., Wien. med. Wchnschr., 1928, Ixxviii, 1340. Kalkuntersuchungen bei Skeletterkrankungen.

27. Beck, A., Arch. f. klin. Chir., 1928, clii, 123. Case Report.

28. Barr, D. P., Bulger, H. A., Dixon, H. H., J. Am. Med. Assoc., 1929, xcii, 951. Hyperparathyroidism.

29. Wilder, R. M., Endocrinology, 1929, xiii, 231. Hyperparathyroidism: Tumor of the Parathyroid Glands Associated with Osteitis Fibrosa.

30. Boyd, Julian D., Milgram, J. E., and Stearns, G., J. Am. Med. Assoc., 1929, xciii, 684. Clinical Hyperparathyroidism.

31. Snapper, L., Nederlandsch Tijdschrift voor geneeskunde, 1929, lxxiii, 4758. Gezwel Van Een Bijschildklier en Skeletafwijkingen.

32. Mandl, F., Zentralbl. f. Chir., 1929, lvi, 1739. Zur Frage der Exstirpation eines Epithelkörpertumors bei der allgemeinen Ostitis Fibrosa.

33. Hunter, D., Proc. Roy. Soc. Med., 1929, xxiii, 27. Hyperparathyroidism. (Hyperfunction of a Parathyroid Tumour in a Case of Generalized Osteitis Fibrosa.) 